\title{
Study of High Rise Residential Buildings in Indian Cities (A Case Study -Pune City)
}

\author{
Rupali Kavilkar and Shweta Patil
}

\begin{abstract}
High-rise structures are also called "vertical cities", having the potential to decongest urban sprawl. Indian cities are witnessing immense demographic expansion due to migration from surrounding villages, leading to urban sprawl, housing demand, rise in cost of land. Housing has developed into an economy generating industry. Given this demand, while high-rise residential structures have become a solution in the metropolitan cities, they remain eluded in tier II cities in India. Low-rise or mid-rise high-density dwelling types have developed in these cities. A study of Pune city's housing needs, demands, market, and type of structures being built, reveal that tall buildings of 11 floors are being developed on the city's urban fringe. Most of the high-rise projects remain as proposals. An investigation in this case study reveal that high rise structures are not preferred due to user perception of insecurity in case of fire and high cost of the building. The paper aims at studying the availability and use of fly ash in various proportions, which can be used in Indian high-rise residential buildings. The research paper indicates that fly ash concrete can be used to reduce the cost of construction and has the potential to minimize the damage caused due to high temperature.
\end{abstract}

Index Terms - Fly ash, high-rise residential buildings, Indian cities, Pune city.

\section{INTRODUCTION}

Tall buildings throughout the world are becoming popular day by day. With the advent of modern day construction technology and computers, the basic aim has been to construct safer buildings keeping in view the overall economics of the project. A high-rise building, apartment tower, office tower, apartment block, or block of flats, is a tall buildingor structure used as a residential and or office use. In some areas they may be referred to as "Multi Dwelling Unit" or "Vertical cities". They have the potential to decongest the urban sprawl on the ground level, and increase the urban density, housing higher number of families in lesser space [1]. Benefits include they act as landmarks; create unique skyline and efficient land use [2].

Although there is no precise definition that is universally accepted, various bodies have tried to define what 'high-rise' means:

- The New Shorter Oxford English Dictionary defines a high-rise as "a building having many stories".

- The International Conference on Fire Safety in high-rise Buildings defined a high-rise as "any structure where the height can have a serious impact on evacuation"

- Massachusetts, United States General Laws define a

Manuscript received March 15, 2013; revised July 5, 2013

R .Kavilkar and S. Patil are with the Department of Architecture, KLS Gogte Institute of Technology, Belgaum, 590009, Karnataka, India (e-mail:rdkavilkar@git.edu, shwetapatravali@gmail.com). high-rise as being higher than 70 feet $(21 \mathrm{~m})$.

- Most building engineers, inspectors, architects and similar professions define a high-rise as a building that is at least 75 feet $(23 \mathrm{~m})$ tall.

- The International Building Code (IBC 2000) and the Building Construction and Safety Code, NFPA 5000TM-2002,Paragraph 3.3.28.7 of the Life Safety Code®, 2006 edition, define high-rise buildings as buildings 75 feet or greater in height measured from the lowest level of fire department vehicle access to the floor of the highest occupiable story.

- Considered to be one that extends higher than the maximum reach available to fire fighters. When this happens fire is fought by personnel inside the building rather than from outside.

- The term "high-rise building" means any building having an occupied floor(s) located more than 75 feet above the lowest level of Fire Department vehicle access.

- The Mumbai Municipal Corporation (BMC) proposed that any building with a height of $30 \mathrm{~m}$ (nine floors) be categorized as a high rise. This is an increase of $6 \mathrm{~m}$ from the existing definition ( $24 \mathrm{~m}$ or seven floors).

- But from the structural point of view it can be defined as the a building that its height will be affected by lateral forces resulting from earthquakes and wind forces to extent that such forces will play a major role in the process of design.

Based on the distribution of the components of the primary lateral load-resisting system over the building, the structural system of high-rise buildings can be broadly classified as [3]:

Interior Structures

Exterior Structures

- In interior structural system, the major part of the lateral load-resisting system is located within the interior of the building. Whereas in exterior structural system, the lateral loads resisting system, is located along the building perimeter.

\section{High RISE STRUCTURES IN INDIA}

Indian cities are witnessing immense demographic expansion due to migration from surrounding villages, leading to urban sprawl, housing demand, rise in cost ofland. Many citizens all over India migrate to the cities for better jobs and education. Industries, trade and commerce activities and number of educational centres in cities attract floating population from all their surrounding villages and districts. This has expanded the cities in all directions and all aspects of development. With an urban sprawl of kilometres, these face the problems of congestion, pollution, everyday commuting to work place, competition, deforestation etc. 
The development can be categorized in four categories considering different philosophy:

High Rise with High Density; High Rise with Low Density; Low Rise with High Density; and Low Rise with Low Density.

In India, a building greater than $75 \mathrm{ft}(23 \mathrm{~m})$, generally 7 to 10 stories, is considered as high-rise. Also a building is considered to behigh-rise when it extends higher than the maximum reach available to fire fighters. According to the building code of India, a tall building is one with four floors or more or a high-rise building isone 15 meters or more in height [4].Most of the tall buildings in India are in the commercial capital Mumbai. More than 2500 high-rise buildings are already constructed. In addition more than thousand mid-rises exists already in the city. Mumbai is undergoing a massive construction boom, with thousands of tall buildings and about fifteen high-rise structures are under construction. Delhi and its surrounding regions are witnessing huge construction activities with 1500 already constructed high-rises.

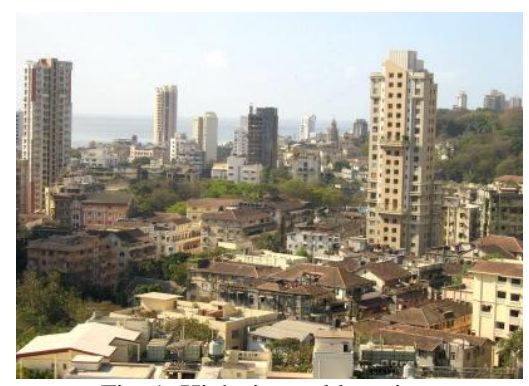

Fig. 1. High rise and low rise.

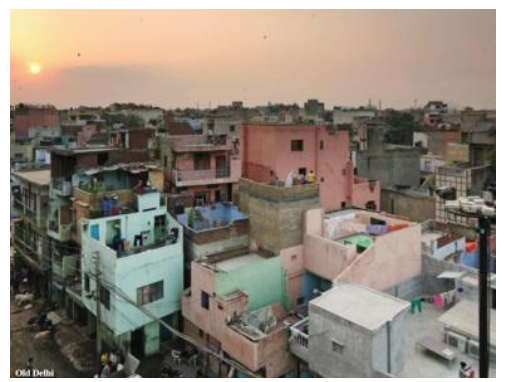

Fig. 2. A congested area in Delhi housing in Mumbai city.

\section{CASE STUdY - PUNE CITY}

Pune is the seventh largest city in India and second largest city in Maharashtra ${ }^{1}$ after Mumbai [5]. Pune Municipal Corporation (PMC) jurisdiction extends up to an area of 243.84 sq. km. housing 2.54 millionpopulace within 144 wards. Referred as 'Detroit of India', the city has experienced a long standing urbantradition: first as an historical centre of pre-colonial urbanism, then as an important military centre duringBritish rule, after independence as a rapidly growing contemporary industrial centre, and today identified asa growing metropolis. Additionally, Pune ispopularly nicknamed as 'Queen of Deccan', 'Pensioners Paradise', 'Cultural Capital of Maharashtra', 'CyberCity' etc. owing to its location, pleasant climate, historical importance, educational hub, vibrant culture and upcoming Information technology centres [6].

${ }^{1}$ A state in India, with Mumbai as capital and pune as second largest city.
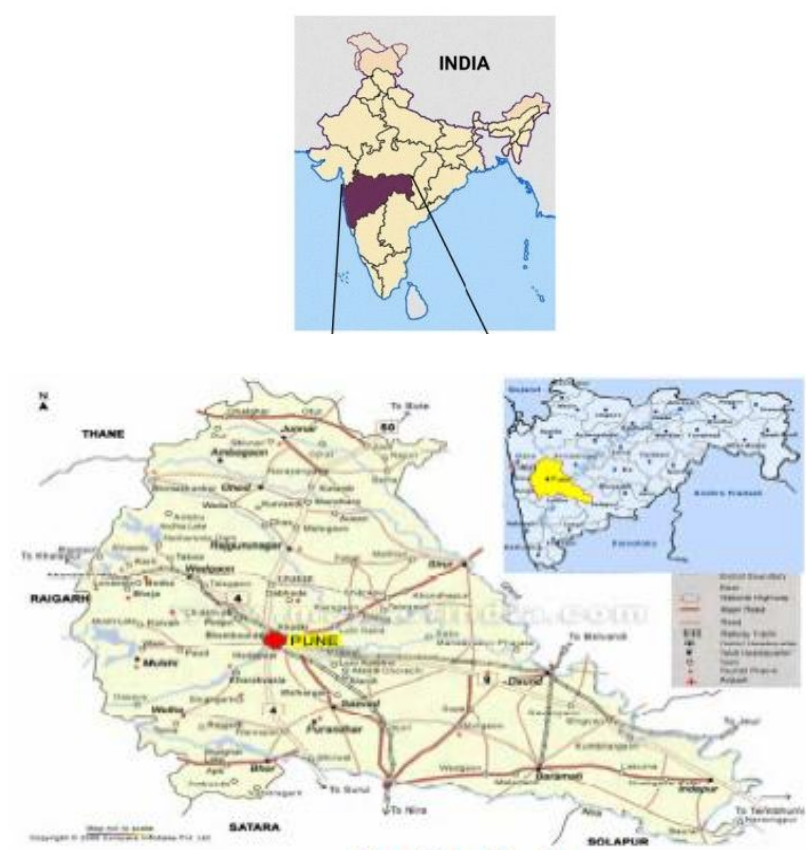

Fig. 3. Location of Pune city.

Pune Municipal Corporation has a population of 2.54 million (2001) which accounts for 35 percent of the total urbanpopulation in Pune District and 60 percent of total PMR population. The PMC's population has grown from 1.57 million in 1991 to 2.54 million in 2001 as in Fig. 4, and in the last decade experienced acompounded annual growth rate of 4.94 percent [5]. PMC's growth is not limited to few but influenced by variousfactors. It is the most preferred destination for many citizens in Maharashtra for job, education, healthcare treatment, real estate investment, better quality of life etc. as Mumbai is already crowded, complied with comparatively high cost of life. Rapid growth ofthe city however mainly attributed to industrialization of PMC/PCMC after 1960 and expansion of Information Technology (IT) industry in the last decade.

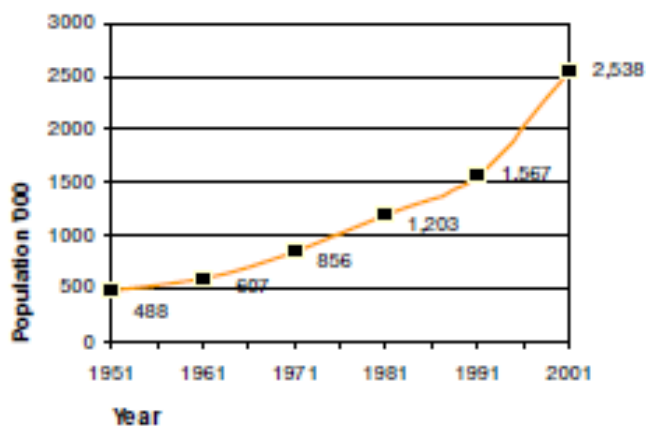

Fig. 4. Graph showing growth of population in Pune.

\section{High Rise Residential BuILdings in PunE}

Till a few years back, the maximum height of buildings in Pune was 36 metre. In November 2007, TheGovernment of Maharashtra allowed construction of tall buildings in other cities also. Based on the approval ofthe State Government, the Pune Municipal Corporation permitted builders to construct 100 metre tall buildings.

\section{A. High-Rise Building Utilization.}

- Single tenant / single use: -e.g. A bank building where the 
business of the bank only is conducted.

- Single tenant /multiple uses: -e.g. A bank building with parking, restaurants, retail outlets and facilities open to public.

- Multiple tenant / Single use:-e.g. IT Park, Medical office building, Residential use.

- Multiple tenant / Multiple uses:-e.g. Commercial office Buildings. [7].

TABLE I: HIGH RISE STRUCTURES IN PUNE

\begin{tabular}{|l|c|c|c|c|}
\hline $\begin{array}{c}\text { Building, } \\
\text { Location }\end{array}$ & $\begin{array}{c}\text { No of } \\
\text { Floors }\end{array}$ & Type & Year & Status \\
\hline $\begin{array}{l}\text { Yoo Pune 1 to } \\
\text { 6,Pune }\end{array}$ & 30 & High rise & 2012 & Proposed \\
\hline $\begin{array}{l}\text { Blue Ridge } \\
\text { B1-5, Pune }\end{array}$ & 26 & High rise & 2012 & Proposed \\
\hline $\begin{array}{l}\text { Windere 1\&2, } \\
\text { Pune }\end{array}$ & 24 & High rise & 2012 & Proposed \\
\hline $\begin{array}{l}\text { ABIL God's } \\
\text { Blessing, Pune }\end{array}$ & 23 & High rise & 2012 & Proposed \\
\hline $\begin{array}{l}\text { Blue Ridge } \\
\text { 5-21, Pune }\end{array}$ & 23 & High rise & 2012 & Proposed \\
\hline
\end{tabular}

TABLE II: TALL STRUCTURES IN PUNE

\begin{tabular}{|c|c|c|c|c|}
\hline $\begin{array}{l}\text { Building, } \\
\text { Location }\end{array}$ & $\begin{array}{l}\text { No of } \\
\text { Floors }\end{array}$ & Type & Year & Status \\
\hline Aurora Towers & 11 & $\begin{array}{l}\text { low-rise } \\
\text { building }\end{array}$ & 2008 & Completed \\
\hline $\begin{array}{l}\text { Parmar Trade } \\
\text { Centre }\end{array}$ & 11 & $\begin{array}{l}\text { low-rise } \\
\text { building }\end{array}$ & 2008 & Completed \\
\hline $\begin{array}{l}\text { Pataliputra } \\
\text { Complex }\end{array}$ & 11 & $\begin{array}{l}\text { low-rise } \\
\text { building }\end{array}$ & 2008 & Completed \\
\hline $\begin{array}{l}\text { Orchid - VITS } \\
\text { Hotel }\end{array}$ & 11 & $\begin{array}{l}\text { low-rise } \\
\text { building }\end{array}$ & 2008 & Completed \\
\hline VITS Hotel & 11 & $\begin{array}{l}\text { low-rise } \\
\text { building }\end{array}$ & 2008 & Completed \\
\hline $\begin{array}{l}\text { Le Meridien } \\
\text { Hotel }\end{array}$ & 10 & $\begin{array}{l}\text { low-rise } \\
\text { building }\end{array}$ & 2008 & Completed \\
\hline Le Mirage & 10 & $\begin{array}{l}\text { low-rise } \\
\text { building }\end{array}$ & 2008 & Completed \\
\hline $\begin{array}{l}\text { Vishal [DSK } \\
\text { Raanwara] }\end{array}$ & 10 & $\begin{array}{l}\text { low-rise } \\
\text { building }\end{array}$ & 2009 & Completed \\
\hline G N Satellite & 10 & $\begin{array}{l}\text { low-rise } \\
\text { building }\end{array}$ & 2010 & Completed \\
\hline $\begin{array}{l}\text { EON Free Zone } \\
4 \text { [EON Free } \\
\text { Zone] }\end{array}$ & 10 & $\begin{array}{l}\text { low-rise } \\
\text { building }\end{array}$ & 2010 & Completed \\
\hline $\begin{array}{l}\text { Lemon Tree } \\
\text { Hotel } \\
\text { Hinjawadi }\end{array}$ & 10 & $\begin{array}{l}\text { low-rise } \\
\text { building }\end{array}$ & 2009 & Completed \\
\hline $\begin{array}{l}\text { Hyatt Regency } \\
\text { Pune } 1\end{array}$ & 10 & $\begin{array}{l}\text { low-rise } \\
\text { building }\end{array}$ & 2009 & Completed \\
\hline $\begin{array}{l}\text { Hyatt Regency } \\
\text { Pune } 2\end{array}$ & 10 & $\begin{array}{l}\text { low-rise } \\
\text { building }\end{array}$ & 2009 & Completed \\
\hline $\begin{array}{l}\text { Pride } \\
\text { Aashiyana } 5 \\
\text { [Pride } \\
\text { Aashiyana] }\end{array}$ & 10 & $\begin{array}{l}\text { low-rise } \\
\text { building }\end{array}$ & 2012 & $\begin{array}{c}\text { Under } \\
\text { construction }\end{array}$ \\
\hline $\begin{array}{l}\text { Pride } \\
\text { Aashiyana } 6 \\
\text { [Pride } \\
\text { Aashiyana] }\end{array}$ & 10 & $\begin{array}{l}\text { low-rise } \\
\text { building }\end{array}$ & 2012 & Completed \\
\hline $\begin{array}{l}\text { EON Free Zone } \\
3 \text { [EON Free } \\
\text { Zone] }\end{array}$ & 10 & $\begin{array}{l}\text { low-rise } \\
\text { building }\end{array}$ & 2010 & $\begin{array}{c}\text { Under } \\
\text { construction }\end{array}$ \\
\hline $\begin{array}{l}\text { EON Free Zone } \\
2 \text { [EON Free } \\
\text { Zone] }\end{array}$ & 10 & $\begin{array}{l}\text { low-rise } \\
\text { building }\end{array}$ & 2009 & $\begin{array}{c}\text { Under } \\
\text { construction }\end{array}$ \\
\hline
\end{tabular}

The above comparison indicates that tall residential and mixed use buildings havebeen constructed and occupied [8]. But high rise structures in Pune have remained as proposals. Though suburb areas like Hinjewadi developed as IT hub, have witnessed high rise structures, most of the city and its peripheral suburbs have developed tall structures for residential use and eluded high rise structures[8].

It is costlier to make high-rise buildings because of the design factors: the vertical members like the columns have to be much stronger and as it raises the cost and time of transportation and scaffolding. Thus the price of flats becomes higher and in case of 30 floors, the cost of flat would be about $40 \%$ more than that on the first floor. Further the maintenance becomes very costly compared to a conventional low height building [8].

Four property account for the majority high rise fires, office buildings, hotel, apartment buildings and hospitals. Most high rise building fire and associated losses occur in apartment buildings [9].

After the 11 September 2001 terrorist attack, more people have developed aversion to staying in high risebuildings[9].

\section{B. Analysis of Perception of Potential Dwellers}

Many buyers are unwilling to stay in high rise structures due to high cost of residential units and as they are unsure about the effectiveness of firefighting measures. Some are also afraid about evacuation in case of earthquake[8].

\section{MAterials USED IN THE CONSTRUCTION OF High-Rise BUILDINGS IN INDIA}

Concrete is an incredibly strong manmade mixture of aggregate (sand and gravel), cement and water that has been used in construction since Roman times. It is very hard and in its normal state can withstand high compression loads but it has one major weakness - it cannot resist tension loads.

Many factors will affect how concrete will behave under fire conditions [10]. These may include:

- Quantity and type of aggregate used in the mix

- Thickness (and thus protection of reinforcement)

- Type of Cement used

- Water content of the concrete

- Load bearing

- Fire Exposure time

- Temperature

- Application of water (fire fighting Jets)

- Cladding or covering

- Age

The failure of the concrete slab usually occurs in the form of spalling which is the progressive deterioration of the surface exposed to heat. This is because the aggregate element usually containsquartz, which will start to crack and disintegrate at $600^{\circ} \mathrm{C}$.

It is the type and quantity of aggregate in the concrete mix that will define its inherent fire behavior of concrete in fire resistance properties.

Steel is extensively used in all forms of construction and is present in nearly inevery form of reinforced concrete.

Steel is a metal alloy whose major component is iron. Carbon is added and this acts as a hardener. Because of its limitations in fire, if used in a structural context, steel is usually given additional fire protection, inthe form of a sacrificial cladding or a barrier. The steel work buried within reinforced concrete is to a large degree protected from fire by the concrete covering it, but prolonged exposure to high temperature can affect the integrity or the tensioning within 
concrete, leading to failure.

High strength and the development of modern glass construction techniques means that many new high rise buildings use large quantities of glass as walling (usually supports by steel framework). This technique is seldom used in residential accommodation, but all windows are of glass held in by a variety of framing materials.

Aluminum is a relatively soft and light metal with a melting point of $660^{\circ} \mathrm{C}$. Its lightness means it has uses in the construction industry for non-structural items, such as door and window frames and external cladding. It is important to note that exposure to high temperatures will lead to early failure and if these frames form part of the fire resistance of the building (either compartmentation within lobby's or as windows between floors) integrity can be affected.Aluminum as an external cladding can melt if exposed to fire and the falling molten aluminum possess additional hazards.

\section{FLY ASH}

In India, coal will continue to remain a major source of fuel for power generation. At present, about $60 \%$ power is produced by using coal as fuel, which results in the production of about112milliontonsofflyashperannum. Considering the tremendous growth required in the power sector for the development of Indian economy, it is expected that ash generation will reach 225 million tons by 2017 .

Ash is good resource material for utilization in various areas such as manufacture of cement, cementconcrete, embankment construction, lowlying area filling etc.

The major utilization areas of flyash are as under: -

1) Manufacture of Portland Pozzolana Cement \& Performance improver in Ordinary Portland Cement (OPC).

2) Part replacement of OPC in cementconcrete.

3) High volume fly ash concrete.

4) Roller Compacted Concrete used fordam\& pavement construction. Use of ash in road embankment

5) Manufacture of ash bricks and other building products.

6) Construction of road embankments, structural fills, low lying area development.

7) As a soil amender in agriculture and wasteland development.

\section{A. Examples of Use of Flyash in Concrete-Worldover}

Worldover fly ash has been successfully utilized in cement concrete and as component of Portland Pozzolana Cement/ Blended cement for more than 50 years. Some of the structures wherein fly ash has been utilized are as under:

1) Fly ash concrete was used in Prudential Building the first tallest building in Chicago after World war II.

2) About $60,000 \mathrm{~m}^{3}$ of fly ash concrete with an estimated saving of 3,000 tonne of Ordinary Portland Cement was used in Lednock Dam construction in UK during the year 1955 .

3) About $60,000 \mathrm{~m}^{3}$ of fly ash concrete with $80 / 20$ Ordinary Portland Cement/ fly ash having average slump of 175 $\mathrm{mm}$ was used in the piles and the foundation slab to meet the requirement of sulphateresistance concrete of Ferrybridge C power station in UK during 1964.

4) Fly ash concrete was used for all the tunnel lining and slip formed surge shafts at the Dinorwig Pumped Storage Scheme in the year 1979 \& 1980 in UK mainly to provide increased resistance to attack from aggressive water.

5) In the 1980's, in Sizewell B Nuclear Power station fly ash has been used in about $3,00,000 \mathrm{~m}^{3}$ concrete to improve workability for pumping, reduce temperature rise and increased resistance to chlorides and reduced risk of alkali aggregate reaction.

6) Fly ash in concrete was used in construction of Euro Tunnel-second largest rail tunnel in the world during 1987-94. To meet the early stripping requirement, a concrete mix containing $30 \%$ fly ash with w/c of 0.35 using high efficient water reducing admixture at a total cementitious content of $440 \mathrm{~kg} / \mathrm{m} 3$ was used in the work. The strength of concrete obtained was more than $80 \mathrm{MPa}$ at 28 days and permeability coefficients were $10-13 \mathrm{~m} / \mathrm{s}$ against requirement of $70 \mathrm{MPa}$ and $10-11 \mathrm{~m} / \mathrm{s}$.

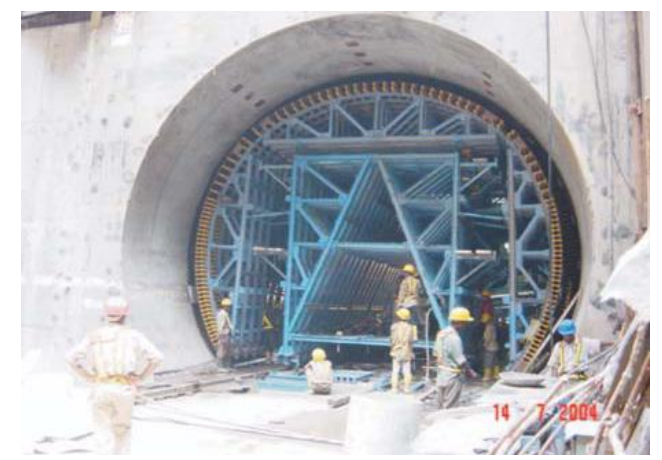

Fig. 5. View of tunnel of Delhi Metro Rail Corporationwhere fly ash has been used.

7) Fly ash has been used in construction of world's tallest building "Petronas towers of Kuala Lampur. The concrete used in the building was of two grades $80 \mathrm{MPa}$ and $60 \mathrm{MPa}$. The fly ash content was about $37.5 \%$ of total cementitious content in mix. Construction completed in the year 1998.

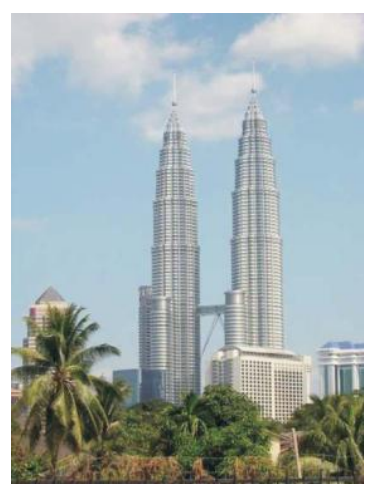

Fig. 6. Petronas tower

\section{B. Behavoir of Flyash at Elevated Temperatures}

The role of fly ash on the behavior of hardened concrete with partial replacement of cement with fly ash in compression under sustained elevated temperatures is reported that with replacement levels of $35 \%, 40 \% \& 45 \%$ by mass of cement and after curing they were exposed to temperatures $200^{\circ} \mathrm{C}$ and $300^{\circ} \mathrm{C}$ sustained for period of 5 hours [11]. The specimens were allowed to cool to room temperature and then tested under compression. Based on the 
compressive strength, it could be concluded that blending with fly ash is a viable technique to sustain concrete at elevated temperatures. It was also seen elsewhere that by replacing cement with fly ash the behavior of concrete is better at high temperature [12].

The properties of materials used in preparing concrete play an important role on the performance of concrete during its lifetime. Terrorist attack, accidental fire breakout and different type of explosions produce a rapid change of temperature for a short period. In such a situation, the material properties play an important role in minimizing the potential damage due to high rise of temperature. In recent days, the use of fly ash has been rapidly increased due to need of high performance concrete.

The test results indicate that the mortar containing 50\% fly ash as a replacement of cement exhibits greater resistance to high temperature [13].

\section{CONCLUSION}

The case study analysis puts forth that high rise residential structures are not popular due to user perception that they are expensive and the associated fear of safety during fire.

The study concludes that fly ash is available abundantly, but not used to it full extent in the construction industry. The study of fly ash as a material reveals that it can be more economical to use fly ash in high rise structure and in minimizing the potential damage due to high temperatures.

\section{REFERENCES}

[1] K. Al-Kodmany and M. Ali "Skyscrapers and place making supporting local culture and identity," Archnet IJAR International Journal of Architectural Research, vol. 16, issue 2, July 2012.

[2] K. Rangawala "Contextual tall buildings in India," CTBUH 2010 World Conference - India, Remaking Sustainable cities in the vertical age, Feb. 3rd-5th 2010.

[3] V. Chandwani, V. Agrawal, and N. K. Gupta, "Role of Conceptual Design in High Rise Buildings," International Journal of Engineering, vol. 2, issue 4, pp. 556-560, July-August 2012.

[4] National Building Code of India 2005, Government of India, New Delhi.

[5] L. KantaKumar, N. Sawant, and S. Kaur " Forecasting Urban growth bases on GIS, RS \& SLUETH model in Pune Metropolitan area," International Journal of Geomatics and Gosciences, vol. 2, no. 2, 2011.
[6] Pune Municipal Corporation. Pune and Growth direction. Comprehensive mobility plan for Pune city. [Online]. Available: http://www.punecorporation.org/pmcwebn/informpdf/CMP/Chapter\% 203\%20formatting\%20-3\%20July.pdf

[7] P. Ahluwalia. Security, safety of High-rise buildings and non-core Police duties. [Online]. Available http://www.assocham.org/events/recent/event_743/Pawanjit-Ahluwali a_Premier_Shield_Group.pdf

[8] D. M. Sundrani, "Consumer perception towards tall buildings," Journal of Bussiness and management, vol. 4, issue 4, pp. 16-19.

[9] J. R. Hall Jr, "High rise building fires," National Fire Protection Association, 2005.

[10] Construction materials high-rise fire fighting developing better responses to fires in high-rise buildings. [Online]. Available: http://www.highrisefirefighting.co.uk/material.html

[11] K. N. Vishwanath and N. Suresh, "Fly ash composite concrete under sustained elevated temperature," International Journal of Engineering Research \& Technology, ISSN: 2278-0181, vol. 1, issue 5, July 2012.

[12] M. A. Hossain, M. N. Islam, and M. R. Karim, "Fire resistance of cement mortar containing high volume fly ash," presented at 31st conference on our world in concrete \& structures, August 16th-1 $17^{\text {th }}$ 2006, Singapore.

[13] K. Arunachalam and R. Gopalakrishnan, "Experimental Investigation on high performance fly ash Concrete in normal and aggressive environment," presented at 29th conference on our World in concrete \& structures, 25-26 August 2004.

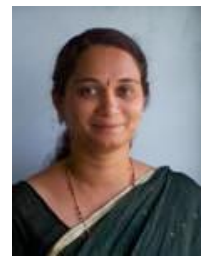

Rupali Kavilkar was born in Belgaum, on September 4, 1971. She received B. Arch from D.Y.Patilcollege, Kolhapur in 1994 and M. Arch General from YCMOU, Nashik. She worked in Muscat, Sultanate of Oman as Architect from 1995 -2004. Since 2004 working as assistant professor in GogteInstitute of Technology college, Belgau. Her research interest is study of political ideologies on urban development.

Her registered for Phd in the Guide- Dr Ravindra Deshmukh, Dr.B. N College of Architecture, Pune University, Indian Institute of Architects,Council of Architecture. Her Publications include Relevance of Indian traditional living patterns to sustainable development in International IIA Youth festival, Chandigarh 2011; Relevance of Conserving the Fort Precinct- A city within a city(A case study- Belgaum Fort) in Journal of Architecture, Dec. 2012

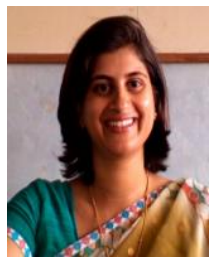

Prof Shweta Patil was born in Belgaum on April 2, 1978 She received her B. E. (civil) from Gogte Institute of Technology, Belgaum and M.Tech Structural from .Gogte Institute of Technology, Belgaum. Since 2004. She is working as assistant professor in Gogte Institute of Technology college, Belgaum. Her research insterest is study of properties of fly ash concrete at elevated temperature.

She registered for Phd in the Guide- Dr K.B.Prakash, Principal of Haveri Engineering College Visvesvaraya Technological University. 